\title{
APLIKASI GAME EDUKASI LINGKUNGAN AGEN P VS SAMPAH BERBASIS ANDROID MENGUNAKAN CONSTRUCT 2
}

\author{
Indu Indah Purnomo \\ Fakultas Teknologi Informasi, Universitas Islam Kalimantan MAB Banjarmasin \\ Email :indumbc@gmail.com
}

\begin{abstract}
Media pembelajaran yang bagus merupakan salah satu sarana penting penunjang kesadaran masyarakat untuk membuang sampah pada tempatya. dengan majunya teknologi saat ini menawarkan pembaharuan dalam pembuatan media pembelajaran. Salah satu bidang penting adalah Pembuatan game edukasi dimana ketika seorang pemain memainkan game ini, secara tidak langsung akan menanamkan rasa peduli terhadap lingkungan sekitarya. Aplikasi yang bernama construct 2, dimana pada construct 2 kita dapat membuat game $2 D$ dan juga pada construct 2 bisa mengexport game untuk berbagai platform misal seperti OS, windows dan bisa menjadi android. Game edukasi ini diharapkan akan dapat di terima di kalangan masyarakat luas, dan dapat bersaing dengan game game yang sudah banyak di pasaran.
\end{abstract}

Kata Kunci : Android, Construct 2 , Game edukasi, Lingkungn,

\section{PENDAHULUAN}

Seiring bertambahnya penduduk di indonesia maka semakin banyak juga produksi sampah tiap harinya, namun mereka tak menyadari secara langsung dampak dari sampah yang semakin banyak tersebut, jika dibuang sembarangan maka akan terjadi bencana alam yang secara tidak langsung disebabkan oleh banyaknya sampah. Adapun bencana yang sering terjadi akibat sampah adalah bencana banjir. Bencana banjir yang setiap tahun terjadi karena penumpukan sampah pada jalur sungai dan menutup tempat mengalirnya air, bahkan juga sampah yang menumpuk membuat sungai menjadi dangkal.

Sementara yang terjadi sekarang ini pendidikan tentang pengelolaan masalah sampah dan lingkungan hidup masih lah sangat minim dan tidak menarik, oleh karena itu penulis menawarkan sebuah fitur pembelajaran lingkungan terutama mengenai masalah sampah dan lingkungan melalui media pembelajaran yang lebih menarik dan interaktif yaitu dengan sebuah game edukasi yang diharapkan dapat memberikan pola pikir yang baik mengenai pengelolaan masalah sampah dan lingkungan.

Game adalah alternatif lain dalam belajar, game selain sebagai media bermain juga dapat di gunakan sebagai media belajar. game yang memiliki fitur bermain dan belajar itu disebut game edukasi. Game edukasi memberikan banyak manfaat bagi pemainnya antara lain dapat meningkatkan daya pikir pemain dan meningkatkan motivasi bagi pemainya serta dalam game edukasi disisipakan pembelajaran maka banyak ilmu yang didapat dalam game edukasi, Study sebelumnya menunjukan kemudahan dalam pengunaan dan kegunaan game edukasi dalam pembelajaran.

Menurut Rizki catur Putra (2015) dalam jurnalnya yang berjudul "Pembuatan game edukasi pintar memilih sampah" menjelaskan bahwa penelitianya tentang pembuatan game edukasi tentang pintar memilih sampah yang menarik dan iteraktif dapat membantu orang tua untuk mendidik dan mengajarkan kepada anaknya tentang membuang sampah yang benar.

\section{LITERATUR}

1) Game

Menurut Wijaya Ariyana \& Arifianto Pengertian Game adalah salah satu kebutuhan sekaligus menjadi masalah besar bagi para pengguna komputer, hal tersebut dikarenakan untuk dapat menjalankan suatu game dengan nyaman, maka dibutuhkan spesifikasi komputer yang relatif tinggi dibanding komputer untuk penggunaan biasa. Dari beberapa pengertian game di atas dapat kita simpulkan bahwasannya Game merupakan suatu program yang dirancang sedemikian rupa untuk memenuhi salah satu kebutuhan manusia, yaitu kebutuhan manusia 
pada hiburan. Hiburan dianggap penting bagi seseorang dikarenakan dengan adanya hiburan akan mampu menyegarkan kembali pikiran mereka setelah disibukkan dengan berbagai aktivitas yang menguras tenaga dan otak. Game bagi anak-anak dinilai mampu merangsang kemampuan berfikir sekaligus mengasah kemampuan kecerdasan si anak itu sendiri. Karena di dalam game biasanya dibuat berbagai permasalahan yang harus diselesaikan oleh si pemainnya. Namun kita perlu tahu game apa yang bagus untuk perkembangan anak, karena tidak semua game pantas untuk dimainkan oleh anak-anak. Maka disinilah peran orang tua sangat penting dalam memantau anak-anak mereka, serta orang tua pun berkewajiban untuk mencari tau game yang pantas untuk dimainkan oleh anak-anak mereka.

\section{2) Game Edukasi}

Edukasi merupakan proses yang terjadi disaat seorang anak manusia telah menemukan jati diri, yang prosesnya dilakukan melalui pengamatan dan pembelajaran, sehingga hasilnya menjadi suatu tindakan dan prilaku dari anak manusia tersebut. Game edukasi merupakan sebuah permainan dibuat dan dirancang khusus untuk dijadikan sebuah media yang digunakan untuk mengajar orang melalui materi yang berisikan suara, teks, gambar, video, dan animasi, yang pokok materinya membahas suatu subjek tertentu, yang memiliki tujuan untuk dapat memperluas konsep, memberikan pemahaman yang lebih baik dari materi yang mengajarkan sebuah peristiwa sejarah maupun budaya, dan dapat pula mengajarkan pengguna dari game edukasi ini dengan baik, karena mereka dapat bermain sambil belajar dengan mudah.

\section{3) Android}

Pembuatan aplikasi game edukasi lingkungan berbasis android pengan construct 2 ini merupakan aplikasi yang dirancang dalam sistem oprasi android, adapun definisi dari beberapa ahli android salah satunya menurut Safaat (2012) menyatakan bahwa Android adalah sebuah sistem operasi perangkat mobile berbasis linux.Sedangkan menurut J.F. DiMarzio (2008).[7] Android merupakan sebuah sistem operasi 9 berbasis Java yang beroperasi pada kernel Linux 2.6. Android bukanlah sebuah bahasa pemrograman tetapi Android merupakan sebuah lingkungan untuk menjalankan aplikasi. Android menyediakan platform terbuka/open source bagi para pengembang sehingga menjadikan sistem operasi ini sangat digemari di pasaran. Sebagian besar vendor smartphone yang diproduksi adalah berbasis Android. Hal ini juga yang menjadikan banyak pengembang mulai mengembangkan aplikasi berbasis Android.

\section{4) Construct 2}

Construct 2 adalah game editor berbasis HTML 5 yang dikembangkan oleh Scirra Ltd, perusahaan yang berasal dari kota London, Inggris. Game builder ini sebenarnya dirancang untuk game berbasis 2D. Dengan menggunakan Construct 2, pengembang permainan dapat mempublishnya ke beberapa platform seperti HTML 5 website, Google Chrome Webstore, Facebook, Phonegap (Android), Windows Phone, Windows 8. Pada Construct 2 telah disediakan 70 visual effect yang menggunakan engine WebGL. Selain itu juga dilengkapi dengan 20 built-in plugin dan behavior (perilaku objek) sehingga kita bisa membuat sprite, objek teks, mengkoneksikan dengan facebook, menambah musik, memanipulasi penyimpanan data game dan lain sebagainya. Pemanggilan fungsi-fungsi di Construct 2 dilakukan dengan menggunkan pengaturan Events yang telah disediakan. Events merupakan pilihan-pilihan action dan kondisi yang akan menjadi nyawa dalam game, sehingga game akan berjalan sesuai dengan yang diinginkan. Karena berbasis HTML 5, maka preview saat running ketika ingin mencoba game dapat dilakukan pada browser (localhost).

\section{METODE PENELITIAN}

\section{A. Metode Pengumpulan Data}

\section{1.) Observasi}

Teknik observasi dilakukan untuk mengumpulkan data yang terkait dengan aspek functionality, reliability dan compability.

\section{2.) Studi Pustaka}

Teknik pengumpulan data yang dilakukan dengan cara memberikan seperangkat pertanyaan atau pernyataan tertulis kepada responden. Teknik ini dilakukan untuk mengumpulkan data yang terkait dengan aspek playability.

B. Analisis masalah

Dari hasil pengamatan dari game-game 
sejenis yang sudah ada seperti game edukasi yang berjudul game edukasi pintar memilih sampah, game edukasi lingkungan edunvi, dan game edukasi go green $\mathrm{mr}$ trashman. Game yang mengangkat tentang sampah dan mengelola sampah dengan benar, sangat menarik bagi anak dari umur 6-13 tahun selain sebagai bahan edukasi pendidikan usia dini game tersebut juga dapat mengasah pola pikir anak.

\section{Analisis Kebutuhan}

Setelah melakukan kajian dan pengamatan mengenai fitur dan fungsi apa saja nanti yang akan berjalan di aplikasi game edukasi lingkungan "Agen p VS Sampah" berbasis android ini maka dapat di simpulkan kebutuhannya sebagai berikut :

1. Game Agen $\mathrm{p}$ Vs sampah merupakan game yang dimainkan satu orang player dan bersifat Offline.

2. Game Agen $p$ vs sampah merupakan sebuah permainan yang dapat mengasah kemampuan pemain dalam bermain game dan disisipkan edukasi menjaga lingkungan dari sampah yang berhamburan dan sampah yang berterbangan yang dapat menimbulkan penyakit serta bencana jika dibiarkan.

3. Game Agen P Vs sampah ini adalah game yang disediakan beberapa karakter berbeda sehingga diperlukan untuk memilih karakter sebelum bermain.

4. Game Agen P Vs Sampah ini adalah game yang berbasis petualangan dimana akan disajikan dalam berbagai level dengan tingkat berbeda sehingga dibutuhkan untuk memilih level.

5. Pemain akan dapat memilih level yang lebih sulit jika pemain sudah menyelesaikan level sebelumnya yang sudah ditentukan brapa skore yang didapat untuk melanjutkan kelevel game selanjutnya untuk itu diperlukan penampungan data score.

6. Karena game ini mempunyai kesukaran yang berbeda di setiap levelnya maka diperlukan nya sistem Reset agar permainan dapat kembali ke sedia kala.

7. Pemain pasti suatu saat akan mengalami kesusahan dan kendala dalam setiap permainan, oleh karena itu diperlukan menu Help pada bagian menu tampilan saat bermain.

8. Karena game ini berbasis pertualangan maka permainan menggunakan tombol maju mundur dan loncat serta tombol serang ketika sampah berubah jadi virus.

\section{Use Case Diagram}

Rancangan diagram kasus pengguna dari sistem yang dibuat ditunjukkan pada Gambar 1. Sistem memiliki 14 kasus pengguna yaitu, 1) Play, 2) Character, 3) Level, 4) Level1, 5) Game Over, 6) Berhasil, 7) Score, 8) Level2, 9) Game Over2, 10) Berhasil2, 11) Score2, 12) LevelN, 13) Setting, 14) Exit.[2]

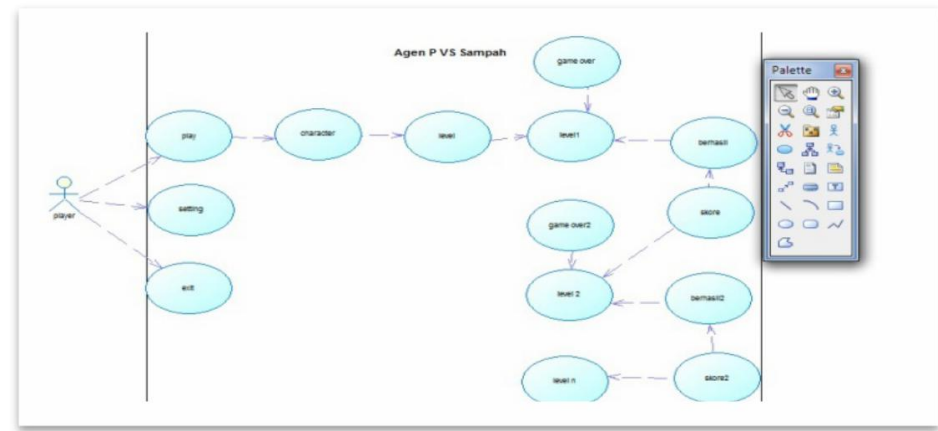

Gambar 1. Use Case Diagram Aplikasi Game Edukasi

\section{HASIL PENELITIAN}

\section{A. Tampilan Aplikasi}

Star page adalah sebuah tampilan awal game dimana pada awal game ini kalian harus menyentuh tombol start agar dapat lanjut ke page atau layout selanjutnya untuk bermai game

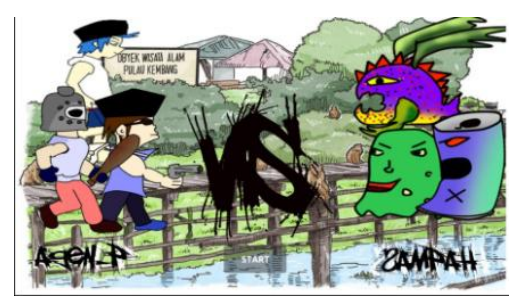

Gambar 4.1Start Page

Pada menu utama ini kalian akan disajikan beberapa tombol yaitu terdiri dari tombol character, setting dan exit.

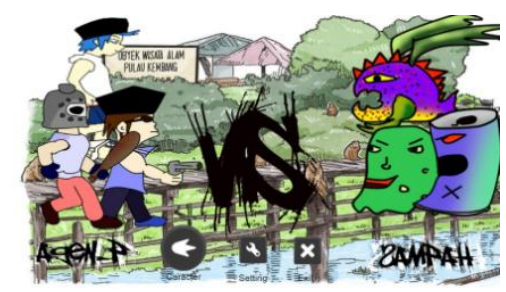

Gambar 4.2 Layout Menu Utama Game 
Pada layout ini merupakan lanjutan dari menu utama ketika kita menekan tombol setting dimana pada menu ini kita akan mensetting audio dari game ini

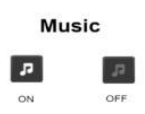

Gambar 4.3Layout Setting

Pada layout ini kalian akan memilih character mana yang akan dijadikan pemain atau player untuk melalui permaiana dan rintangan yang ada pada saat memainkan game.

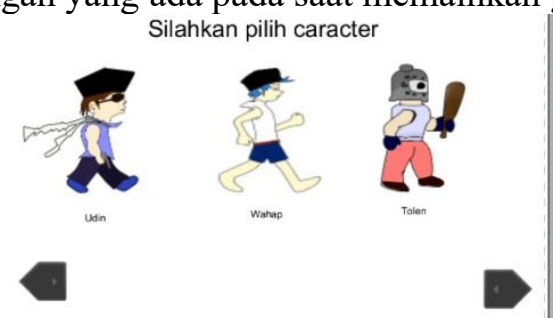

Gambar 4.4Layout character

Pada layout ini akan di temukan ketika pemain sudah memilih character, dan tiap level akan berbeda tingkat kesulitanya, dan level akan terbuka jika sudah menyelesaikan level sebelumnya sehingga pemain harus menyelesaikan setiap levelnya.

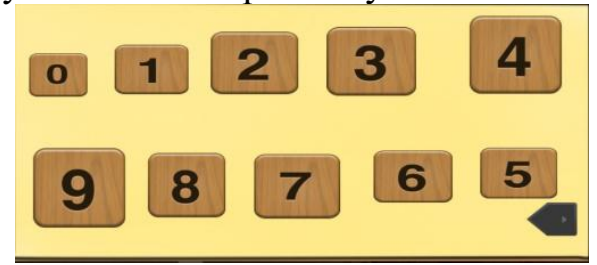

Gambar 4.5Layout level

Pada layout ini terbagi dari beberapa item dari layout, yaitu item control pergerakan character, item healt atau darah pemain, dan juga item lainya

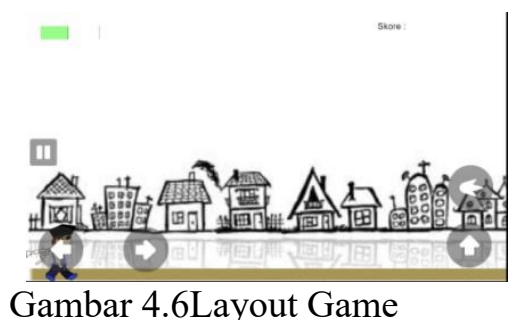

Pada layout ini pemain akan di berikan berupa informasi tentang sampah dan bagaimana menanganinga sehingga pemain tidak hanya bermain dalam game ini pemain juga dapat informasi tentang sampah dan penangananya.

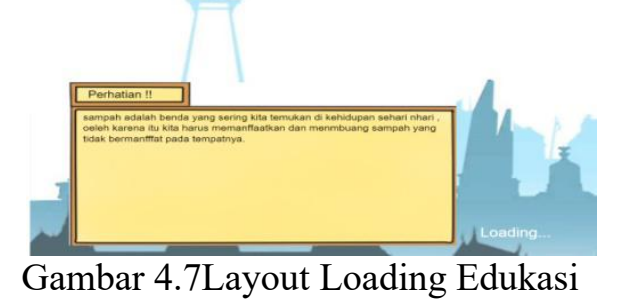

\section{B. Hasil Pengujian Aplikasi}

Untuk dapat menilai kesesuaian antara rancangan dan aplikasi yang dibuat, selanjutnya dilakukan pengujian dengan menggunakan metode Black Box Testing. Dari seluruh hasil pengujian dapat disimpulkan aplikasi telah sesuai dengan rancangan. Hasil pengujiannya ditunjukkan pada Tabel II.

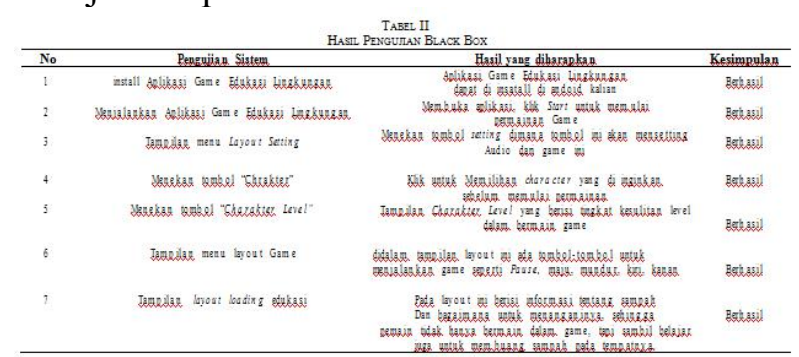

\section{KESIMPULAN}

Bedasarkan penjelasan yang telah diuraikan di atas, Maka dapat disimpulkan berbagai hal sebagai berikut:

1. dengan adanya game edukasi ini para orang tua terbantu untuk mengajari anaknya untuk menjaga dan menyayangi lingkungan.

2. sebagai game edukasi tentunya banyak ilmu yang didapatkan, anak - anak bermain sambil belajar mengenali sampah.

3. pada akhirnya limbah sampah yang di sebabkan oleh orang yang membuang sampah sembarangan akan berkurang, karena adanya kesadaran masyarakat terutama pemain game ini untuk menjaga lingkungan, dan bahaya yang ditimbulkan sampah.

\section{REFERENSI}

[1] Fridyatma, T.I. (2015), Jurnal rancang bangun game edukasi go green"Mr.trashman" Menggunakan 
adobe flash. Bandung.

[2] Indu, I.P. (2019). Aplikasi layanan Angkutan Kapal di PT. Pelayaran Tempuran Emas, Tbk Banjarmasin Berbasis Web. Technologia: Jurnal Ilmiah. 10.2: 101-104.

[3] Muhammad, E.R. dan. I.I. Purnomo. (2018). Rancang Bangun Media Pembelajaran Seni Dan Budaya Suku Banjar Berbasis Augmented Reality. Jurnal Teknologi Informasi Universitas Lambung Mangkurat (JTIULM). 3.2: 53-58.

[4] Muhammad, E.R. I.I. Purnomo. dan. M.I. Firdaus. (2018). Pengembangan Sistem Informasi Penerimaan Mahasiswa Baru Dengan SMS Gatwey (Studi Kasus Universitas Islam Kalimantan). Technologia: Jurnal Ilmiah. 9.3: 177-184.

[5] Putra, R.C. (2015). pembuatan game edukasi pintar memilih sampah berbasis android. Surakarta.

[6] Rifai, W.A. (2015). Jurnal pengembangan Game edukasi lingkungan berbasis android. Yogyakarta.

[7] Mandalaya. (2016), Pengertian game menurut para ahli. Didapat dari : http://www.mandalamaya.com/pengert ian-game-menurut-para-ahli/.

[8] Ritonnga, P. (2015). Pengertian Unified Modeling Language ( UML) dan Modelnya Menurut Pakar dan Ahli. Didapat dari http://www.bangpahmi.com/2015/04/p engertian-unified-modellinglanguageuml-dan-modelnya-menurutpakar.html.

[9] Wijaya, R. (2015). pengertian edukasi dan game edukasi.didapat dari : http://www.rianfartawijaya.com/2015/ 02/pengertian-edukasi-danpengertian-game.html. 